Article

\title{
A Qualitative Study of Illness Narratives that Demonstrate the Master Plot of Overcoming the Monster and Support stroke survivors in utilising it
}

\author{
Rana Alawafi ${ }^{1,2}$, Sheeba Rosewilliam ${ }^{1}$ and Andrew Soundy,** \\ 1 School of Sport, Exercise and Rehabilitation Sciences, University of Birmingham, B15 2T, United Kingdom \\ 2 Princess Nourah Bint Abdulrahman University, Riyadh, Saudi Arabia \\ * Correspondence: A.A.Soundy@bham.ac.uk
}

\begin{abstract}
Background; limited research exists which considers master plots expressed by individuals with Stroke. The literature so far has focused on identified pre-established illness narrative types; (2). Methods: A narrative method was selected and a purposive sample of individuals with Stroke are identified. A categorical-form analysis was undertaken; (3) Results: A narrative master plot named overcoming the monster is identified and explored for its components and located temporally for each participant; (4) Conclusions: Health care professionals need to understand the importance of understanding the master plot overcoming the monster. This research supports the need for health care professionals to recognise and support narratives by listening in a non-directive way.
\end{abstract}

Keywords: Stroke; Qualitative; Narrative; Master Plot; Experience; Perception

\section{Introduction}

Health care professionals (HCPs) and patients express the effects of a stroke differently, most typically HCPs focus on the identification of physiological and neurological effects, whilst patient identify meaning by interpreting the event in relation to their own biographical history [1]. Current guidelines [2] for best practice illustrate the importance of covering many areas; in the desire to achieve best practice and cover all recommendations, physiotherapists could miss the value of the person's story. Personal account of illnesses are important to create social awareness, to reduce stigma towards the illness and influence research and policies [1]. Telling stories provides the individual with an opportunity to create meaning and (re)establish a sense of social identity [3]. HCPs will benefit from understanding narratives as it will allow a greater access to patients [9], it will also challenge current 'therapeutic emplotment', which is the creation of stories through interactions, helping consider what is said (or not said) and how they act or what they conceal during an interaction [13].

Narratives are often identifiable by genres or master plots. Frank [4] describes this as the "most general storyline that can be recognised underlying the plot" (page 75). The most cited illness narrative master plots are often from this work including the quest, chaos and restitution narratives e.g., [5]. In chronic neurological illnesses including stroke other master plots have been named, for instance Soundy et al., [6] identifies 13 master plots. Other master plots found in history and culture are often portrayed in film [7] give an illustration the most common stories available to people, although, to the best of the authors knowledge they have not yet been considered against illness narrative master plots. One of these types which may be particularly prevalence in stroke is named 'overcoming the monster'. Booker [7] states that this story can be identified when a life is 
threatened by an all-powerful monster, once identified, the hero has to fight and defeat the monster. Typically, in past stories the monster is represented by a creature (e.g., a giant). The creature holds power over the hero. The important part of the story is that the monster or evil is killed and the power it holds overthrown.

This 'overcoming the monster' master plot is important because narrative based studies in stroke have identified elements of it. For instance, the most common metaphors identified alongside the experience of stroke include the terms journey and battle, such metaphors suggest an experience of social disempowerment [8]. Further to this, the idea of recovery being a war and qualities of a person being a fighter are ever-present in stroke [1]. HCPs need to be aware of such metaphors and how this links to this narrative master plot and patient would likely benefit from sharing stories that illustrate this. It is important to recognise that the 'monster' can be represented in different and unique ways for instance this could include the interpersonal challenges, cognitive, physical or emotional functioning [9]. The monster could be identified as symptoms of the stroke directly or experiences associated with having a stroke such as depression due to its high prevalence following a stroke [10], isolation [11], it could also include an individual social identity which is often associated with successful living post stroke [12].

Research is needed that can consider what people use in their stories to illustrate the 'monster' and identify how they overcome that monster so that greater support for the aspects of dealing with the monster is possible. Research is also needed that examines the factors which may influence it, for instance adaptation is influenced by the ability to; reappraise one's situation, make personal choices and accept what happened, the ability to use support networks and learning form others [14]. Alternatively, the ability to access such a story may be influenced by empowering interactions with others or disabling experiences of isolation [15]. It is acknowledged that stroke narratives can vary because of personality, culture and psychological adaptation [12]. However, gaining an insight to individual stories will be an important start to this research. This may be best achieved through a small sample of individuals that can look back on their own journey to narrate greater details of their experiences.

The aim of this study was to identify stories that illustrated the master plot of overcoming the monster and help individuals with Stroke and HCPs understand it and use it to help others.

\section{Materials and Methods}

\subsection{Design}

A narrative methodology was assumed situated within a constructivist view of the world, with a relativist ontology and a subjectivist epistemology [16]. This means that reality is viewed as multiple, and knowledge view as being constructed through interactions and then formed on a psychological level. A standardised framework was used to report methods [17].

\subsection{Researcher characteristics and reflexivity}

The researchers undertaking this research were a white male academic who is 42 years old and a middle eastern female PhD student. People with Stroke were not known to either individual and no information about the researchers was given before the interview.

\subsection{Context}


The setting of the interview was from the researcher's home and delivered across skype in a single time point. This was selected to protect individuals during the COVID-19 outbreak and local restrictions. Prior to the interviews, demographic information was gathered, including gender, age, type of stroke, and time since onset of stroke.

\subsection{Sampling and Participant}

Participants were purposively sampled from a well-known website (not identified to shield individual's identity) that allows advertisement of research projects and a local community group. Individuals interested emailed the authors to arrange an interview following consent procedures. Sample size was selected on the ability to reveal rich aspects of a singular master plot examined through the experiences of individuals, the need of this research was not to claim statistical generalisability but rather to impact the reader and consider how it may transfer to others stories [18].

\subsection{Eligibility}

Participants were included if;(a) Adults who were 18 years of age and over, (b) They were at least 2 years post stroke, (c) any type of stroke was included, (d) individuals had to be able to comprehend and answer questions and communicate through skype or zoom, (e) were able to provide informed consent. Participants were excluded if a translator was required.

\subsection{Ethical approval}

Ethical approval was obtained from the University of Birmingham (ERN number: 170149).

\subsection{Semi-structured interview guide}

A single semi-structured interview was developed and pilot tested. No changes to the guide were made following the pilot interview. The interview schedule had 4 major sections and 29 questions and can be viewed in the Supplementary file. The average interview time taken was 60 minutes.

\subsection{Data analysis}

Following the interviews and data collection, individuals were selected to be part of the analysis if their story represented elements of the narrative master plot overcoming the monster. A categorical-form type of narrative analysis [19] was conducted. Four stages of analysis were undertaken;(1) Open Coding, during the stage the lead author immersed herself in the text and verbatim recorded to identify codes and comments on relevant excerpts in relation to what master plots could be identified and why, (2)A defendable case was made for the identification of master plots by the first author to the supervising author using mind mapping and tables to represent comments. (3) The selection of overcoming the monster plot was made. Identification of the elements of the story was undertaken by answering each of the following questions for the participants who presented it: (a) What was the monster? (b) What needed to be overcome?, (c) How was it overcome?, (d) Consequences and (5) Critical moments. (4) Finally, a description of the master plot from each participant who presented (See supplementary file) and summary of the plot given in tables (see below). 
We used a framework by Andrews [20] to ensure quality with a focus on the story and ability to provide a plot summary for each individual that include a temporal framing, with critical moments identified.

\section{Results}

\subsection{Demographics}

Six participants (59 \pm 14 years; 2 male and 4 female) were selected as the master plot identified was associated with overcoming the monster. See Table 1 for a break-down of information.

Table 1 A breakdown of participant demographics

\begin{tabular}{lllll}
\hline Participant ID & Gender & Age & Time with stroke & Type of stroke \\
\hline $\mathbf{1}$ & Male & 62 years & 15 years & Ischemic \\
\hline $\mathbf{2}$ & Female & 40 years & 13 years & Multifocal \\
\hline $\mathbf{3}$ & Male & 64 years & 12 years & Ischemic \\
\hline $\mathbf{5}$ & Female & 63 years & 8 years & Ischemic \\
\hline $\mathbf{6}$ & Female & 80 years & 16 years & Ischemic \\
\hline $\mathbf{7}$ & Female & 46 years & 4 years & Ischemic \\
\hline
\end{tabular}

3.2 Findings relating to overcoming the monster master plot

Several key findings were identified across participants which helped explain the master plot. Table 2 provides this information. 
Table 2 Showing the break down of component of the overcoming the monster narrative

\begin{tabular}{|c|c|c|c|c|c|}
\hline Participant & What was the monster? & $\begin{array}{l}\text { What needed to be } \\
\text { overcome? }\end{array}$ & How was it overcome? & Consequences & Critical moments \\
\hline 1 & $\begin{array}{l}\text { 1. Threat of the illness on } \\
\text { his mental health, ability } \\
\text { to work and sense of self } \\
\text { 2.The problems and } \\
\text { aspects that went wrong } \\
\text { in hospital }\end{array}$ & $\begin{array}{l}\text { 1. Mobility } \\
\text { 2.Psycholgoical state, not } \\
\text { believing what was } \\
\text { possible. } \\
\text { 3. Motivation and } \\
\text { overcoming the feeling } \\
\text { crushed by the experience } \\
\text { but identifying that it was } \\
\text { possible to improve your } \\
\text { situation. }\end{array}$ & $\begin{array}{l}\text { 1. Identify goals and an } \\
\text { action which are to be } \\
\text { achieved from initial goals } \\
\text { like going to the lavatory } \\
\text { alone, to influencing } \\
\text { research and presenting at } \\
\text { conferences. } \\
\text { 2. Having and benefiting } \\
\text { family support } \\
\text { 3. Fighting for } \\
\text { independence and taking } \\
\text { ground back that } \\
\text { represented him }\end{array}$ & $\begin{array}{l}\text { 1. Achieve } \\
\text { personal goals } \\
\text { 2. Influence } \\
\text { change and help } \\
\text { others. }\end{array}$ & $\begin{array}{l}\text { 1. Identifying that hope is } \\
\text { needed in some form and } \\
\text { there is a danger of false } \\
\text { despair, as much as false } \\
\text { hope. He did this by focusing } \\
\text { on improvement rather than } \\
\text { recovery. } \\
\text { 2.Identification of the need to } \\
\text { change what was wrong with } \\
\text { the health care interactions he } \\
\text { had. A mission was begun. } \\
\text { 3.Having family that support } \\
\text { and encourage at a time or } \\
\text { feeling fragile }\end{array}$ \\
\hline 2 & $\begin{array}{l}\text { 1. The internal view of her } \\
\text { situation and the mental } \\
\text { health experiences that } \\
\text { resulted } \\
\text { 2.The difficulty and } \\
\text { challenge faced when } \\
\text { trying to change her } \\
\text { situation and obtain } \\
\text { support. }\end{array}$ & $\begin{array}{l}\text { 1. The isolation and feeling } \\
\text { of being abandoned } \\
\text { 2. being able to support her } \\
\text { children independently }\end{array}$ & $\begin{array}{l}\text { 1. Need to 'fight' with } \\
\text { social services to get } \\
\text { support for her children } \\
\text { 2.Sought counselling } \\
\text { 3. identified a need to help } \\
\text { herself } \\
\text { 4.volunteering }\end{array}$ & $\begin{array}{l}\text { 1. Being able to } \\
\text { help others with } \\
\text { a stroke who } \\
\text { faced similar } \\
\text { difficulties }\end{array}$ & $\begin{array}{l}\text { 1. Feeling abandoned in } \\
\text { hospital } \\
\text { 2. Getting support for } \\
\text { children }\end{array}$ \\
\hline 3 & $\begin{array}{l}\text { 1.The physical effects of } \\
\text { the stroke and impacting } \\
\text { on the ability to leave } \\
\text { hospital and on living } \\
\text { post discharge } \\
\text { 2.The inability to move } \\
\text { 3. The doubt from health } \\
\text { care professionals around } \\
\text { the benefit of activities } \\
\text { selected }\end{array}$ & $\begin{array}{l}\text { 1.Move in hospital enough } \\
\text { to be discharged } \\
\text { 2. That he wouldn't be back } \\
\text { to normal in 3-6 months as } \\
\text { he had originally thought } \\
\text { post stroke } \\
\text { 3. Continue to work } \\
\text { 4. Mobility and movement } \\
\text { against the odds }\end{array}$ & $\begin{array}{l}\text { 1.Increasing mobility } \\
\text { 2.Identifying who he } \\
\text { wanted to be and who he } \\
\text { did not want to be } \\
\text { 3.Identificaiton of being } \\
\text { determined or 'bloody- } \\
\text { minded' } \\
\text { 4.Undertaking activities } \\
\text { which were not prescribed } \\
\text { persistently in order to } \\
\text { obtain benefit }\end{array}$ & $\begin{array}{l}\text { 1.Using his } \\
\text { disability to help } \\
\text { others by } \\
\text { volunteering }\end{array}$ & $\begin{array}{l}\text { 1.That going back to normal } \\
\text { wasn't going to happen } \\
\text { 2. realising that mobility } \\
\text { could change }\end{array}$ \\
\hline 5 & $\begin{array}{l}\text { 1.Within hospital. The } \\
\text { need to come to terms }\end{array}$ & $\begin{array}{l}\text { 1. Achieved by 'moving on' } \\
\text { and identifying a new life }\end{array}$ & $\begin{array}{l}\text { 1.Identification of what } \\
\text { she wanted to do }\end{array}$ & $\begin{array}{l}\text { 1. Want to give } \\
\text { something back }\end{array}$ & $\begin{array}{l}\text { 1.Coming to terms by herself } \\
\text { with what has happened and }\end{array}$ \\
\hline
\end{tabular}




\begin{tabular}{|c|c|c|c|c|c|}
\hline & $\begin{array}{l}\text { with what was happening } \\
\text { by herself } \\
\text { 2.Being alone and not } \\
\text { being able to identify with } \\
\text { others in a similar } \\
\text { situation } \\
\text { 3.That it didn't have to be } \\
\text { a monster, if support } \\
\text { could be given }\end{array}$ & & $\begin{array}{l}\text { 2.Identificaiton of } \\
\text { achievements made that } \\
\text { linked to what she wanted } \\
\text { to do } \\
\text { 3.Determination to prove } \\
\text { 'everyone' wrong }\end{array}$ & $\begin{array}{l}\text { 2.Becoming a } \\
\text { counsellor and } \\
\text { volunteer at a } \\
\text { hospital } \\
\text { 2. Seek to use her } \\
\text { own experience } \\
\text { to share with } \\
\text { and help others } \\
\text { move on and see } \\
\text { that a 'new' life } \\
\text { is possible. } \\
\text { Identifying to } \\
\text { them that they } \\
\text { didn't have to } \\
\text { seek to be } \\
\text { restored } \\
\text { identify as life as } \\
\text { being over. } \\
\text { 4.being able to } \\
\text { identify, listen } \\
\text { and understand } \\
\text { others in order } \\
\text { to help them }\end{array}$ & $\begin{array}{l}\text { the need to move on soon } \\
\text { after discharge } \\
\text { 2. beginning a journey of } \\
\text { helping others } \\
\text { 3. That health care } \\
\text { professionals were not able to } \\
\text { do what she could. }\end{array}$ \\
\hline 7 & $\begin{array}{l}\text { 1.Mental health including } \\
\text { depression } \\
\text { 2.Lack of motivation and } \\
\text { being disheartened }\end{array}$ & $\begin{array}{l}\text { 1.Motivation to engage in } \\
\text { rehabilitation } \\
\text { 2.Movation to want to } \\
\text { change }\end{array}$ & $\begin{array}{l}\text { 1. Having a significant } \\
\text { other encourage her } \\
\text { 2.Motivated not to let the } \\
\text { other down }\end{array}$ & $\begin{array}{l}\text { 1.Finding a way } \\
\text { out of a place } \\
\text { where mental } \\
\text { health problems } \\
\text { didn't impact on } \\
\text { her and where } \\
\text { symptoms were } \\
\text { different }\end{array}$ & $\begin{array}{l}\text { 1. Experiencing mental health } \\
\text { difficulties and a lack of } \\
\text { motivation } \\
\text { 2. Engagement with her } \\
\text { daughter to create change. }\end{array}$ \\
\hline
\end{tabular}




\subsection{Identification of the monster and what needed to be overcome}

The monster could be identified as the experience of mental health problem or a thought cycle that linked in with a sense of being defeated or crushed and the experience of a different sense of self (P1; P2; P3). For P1 this was overcoming a sense of feeling crushed by the experienced but slowly identifying it was possible to overcome. P3 realised he would not be back to 'normal'in 3-6 months.

A sense of feeling isolation was another monster (P2; P5:P6). This was created by not being able to identify with others in a similar situation (P5), or not being able to have a carer and being dependent on others (P6).

The monster could be seen as the threat to being independent (P1; P2: P3:P6). For instance, experiencing a threat to independence and living, and needing to be open to all change that occurs (P6). The ability to work and earn (P1; P3).

Identification of problems with the health care experience that was seen as a monster that needed to be overcome, although recognised importantly as one that didn't have to exist (P5). The monster could be the negative experience of care received and negative impact on dignity (P1). It was expressed as the difficulty faced when seeking support and care from services and not receiving any (P2), and the doubt suggested by HCPs at what his own rehabilitation activities involved.

\subsection{How was it overcome and consequences}

Three principle ways the monster was overcome, included the character of the person and identification of a fight, ways of instigating change and improvements and goals and achievements. Achievements represented one outcome and the other was the influence and impact on peers and others.

\subsection{The fight and characteristics of the person}

The ability to begin overcoming required motivation, so in some cases there was a change from surviving to fighting back and creating a motivation and want to fight (P1; P2. )Several participants identified with the idea of fighting. This was represented as fighting for independence and taking back control (P1), fighting with social services for extra support for her children (P2), and fighting with and benefiting from treatment (P6). In addition to this several individuals focused on their characteristics which represented them against the monster, that included being determined or bloody minded (P3), determined to prove everyone wrong (P5), motivated not to let someone else down (P7).

\subsection{Ways of instigating change and improvements}

Individuals were firstly able to make further improvements by internally viewing life differently e.g., P5 stated a recognition to moving on early after discharge and identifying a new life. P6 identified this by viewing experiences differently, being open to change and embracing uncertainty as an adventure. P3 was able to make improvements by undertaking specific activities, for instance, activities which were not prescribed, part of overcoming the monster for P3 was overcoming the disbelief from the HCPs. For P1 It was important to start with early goals which were a struggle to achieve for P1, the achievements then lead to bigger and impressive goals. 
Identification of goals which were to be achieved and changing these goals as improvements were made was clearly identified by P1 and P5. For instance, for P1 goals began in the hospital with being able to independently go to the toilet, they existed at his home with goals to ride miles on his recumbent exercise bike (e.g., from his home to Paris) and goals of sharing his experience of health care as part of training for health care professionals.

\subsection{Having an impact on others (consequence)}

One of most consistent consequence and identified benefit was influencing others and wanting to help those who had to do through similar experiences (P1; P2; P3; P5). For instance, P5 had undertaken volunteering at a hospital and had become a counsellor to achieve this.

\subsection{Critical moments within the plot}

Two general moments were represented across individuals, this included moments when they recognised limited or negative support and moments when change was identified.

\subsection{Moments of recognising limited or negative support}

Several participants identified negative moments of support from HCPs. For instance, P1 identified that false despair could be caused through interactions with HCPs, he felt so strongly about this that he became involved in research to change health care. P2 identified feeling abandoned in hospital and P5 was able to help peers in a way she considered that HCPs which is (identifying a key limitation in the service provision).

\subsection{Moment when change was identified or understanding what was possible}

Several, critical moments existed when considering possibilities. This included moment when P1 identified the importance of family at a moment of being fragile, when support helped change his view. In a similar way P7 had identified that a want and need to change her situation was driven from interacting with her daughter and wanting to change for her daughter's sake. P6 had a similar experience of being dependent on others in hospital, however P6 had past experience of seeing life differently and was able to use any experience as an adventure, not sure of what would come from it. P3 identified realising that going back to normal wasn't possible but realising that mobility could change. P5 identified early after discharge a need to leave her old life behind and begin a new one, so there was no looking back.

\section{Discussion}

To the best of the authors knowledge, this is the first study to consider the importance of the master plot overcoming the monster. The monster was represented as mental health difficulties, as the effects of poor experiences to care, and from the loss of a sense of self. Individuals identified a period when overcoming wasn't possible, this may be seen as a time when individual have to survive, as such a time HCPs voices are critical in influence and support from others is critical, although a number identified the internal strength to change.

Overcoming the monster required an ability to see that change needed, to identify a reason to fight for a person like a close other or people that could be helped. These aspects are central to the emplotment of the narrative [13]. HCPs need to be mindful of the 
medical voice that can result from training and influences how they respond to narrative types [21]. HCPs must also acknowledge and be prepared for simultaneous stories to be told by patient [5]. Responding to a highly recognisable (possibly perceived unrealistic) master plot, like Restitution, in a directive way may create a monster. A first step in interacting with narrative master plot may be to understand what the monster may be for the patient or exploring metaphors which could reveal the narrative and empower the individual [8]. Training around the value supportive non-directive interactions could be central to aiding this process e.g., [22]. Also adopting a storytelling approach to therapy may also be importance, since such interventions in stroke are associated with positive psychosocial outcomes such as coping, hope and support [23]. It is possible that particular stories of overcoming the monster are more identifiable and accessible from peers as shown in recent peer interventions [11].

Motivation was gained out of positive and successful experiences and their appeared to be great value in understanding the importance of identifying and focusing on small improvements. This finding can be supported by the significant association between family support with motivation and self-efficacy identified in past research [24]. Supporting independence could be critical to this narrative and seeking positive improvements however small could lead to gains in self-efficacy and an ability to overcome created. This could reflect the importance of careful attention to narrative emplotment [25].

Understanding that the creation of such a plot can take years is important, so health care professionals and patients may need to wait for other plots to be expressed, the initial plots identified by people like wanting to be restored or having no hope require careful support. Rather than focusing on what is wrong with the plot there may be more value in understanding how to motivate individuals by knowing the strategies that enhance adherence [26].

\subsection{Clinical implications}

Overcoming the monster may represent a master plot that evolves over time and may not initially be seen straight after Stroke. It is possible that clinicians recognise more common plots and may seek to correct them, not understanding what the monster is or that their interaction could create it. Seeking to understanding patient metaphors may be one simple step to identifying a 'monster'. This could be metaphors that represent a battle or fight, metaphors that represent their character as a 'fighter' or 'persistent', or other metaphors around the idea of a journey. Further to this acknowledging the value and promoting access to peer narratives that may illustrate how their own 'monster' was overcome could be important within the rehabilitation experience.

One form of monster in the current study was poor interactions with health care professionals. To prevent this training that helps health care professionals understand the psychology of master plots is important and further research needs to consider this. It may be important that health care professionals recognise the importance of individuals with stroke in accessing peer stories and seek to offer a variety of stories in different formats (e.g., groups, tele-based, videos online).

\subsection{Limitations}

Further research is needed that can consider health care professionals responses to this narrative master plot. The applicability of this work may vary depending on the extent of deficits experienced (e.g., language, perception, or memory) or the side of the brain effected (Egberg et al., 2021). 


\section{Conclusions}

Health care professionals need to understand the importance of developing the overcoming the monster narrative master plot and understand what factors influence it. This article supports past evidence around the importance of listening to stories in a non-directive way.

Supplementary Materials: The following are available online at www.mdpi.com/xxx/s1. This includes the supplementary file and individual narrative master plots.

Author Contributions: Conceptualization, AS and RA; methodology, AS and RA; validation, SR and AS; formal analysis, RA and AS; investigation, RA and AS; data curation, AS and RA.; writingoriginal draft preparation, RA and AS.; writing - review and editing, AS and SR; visualization, X.X.; supervision, AS and SR.; project administration, RA. All authors have read and agreed to the published version of the manuscript. Please turn to the CRediT taxonomy for the term explanation. Authorship must be limited to those who have contributed substantially to the work reported.

Funding: This research was supported by the Saudi Arabia Government.

Institutional Review Board Statement: The study was conducted according to the guidelines of the Declaration of Helsinki, and approved by the Institutional Review Board (or Ethics Committee) of University of Birmingham (ERN number: 17-0149).

Informed Consent Statement: Informed consent was obtained from all subjects involved in the study.

Data Availability Statement: Please see supplementary file for additional data.

Acknowledgments: The Saudi Arabia Government for supporting this research.

Conflicts of Interest: The authors declare no conflict of interest.

\section{References}

1. 1. Boylstein, C., Rittman, M., Hinojosa, R. (2007). Metaphor Shifts in Stroke recovery. Health communication, 21; 279-287. https://doi.org/10.1080/10410230701314945

2. 2. Mountain, A., Linday, M. P., Teasell, R., Salbach, N. M., de Jong, A., Foley, N et al. (2020). Canadian stroke best practice recommendations: Rehabilitation, recovery and community participation. Part two: transitions and community participation following stroke. International Journal of Stroke, 15; 789-806. DOI: 10.1177/1747493019897847

3. 3. France, E. F., Hunt, K., Dow, C., Wyke, S. (2013). Do men's and women's account of surviving stroke conform to Frank's narrative genres? Qualitative Health Research, 23; 1649-1659.

4. 4. Frank, A. (1995). The Wounded Story Teller. Chicago University Press. USA.

5. 5. Egberg, A. R., Pluta, A., Poweska, J., Lojek, E. (2021). In search for the meaning of illness: content of narrative discourse is related to cognitive deficits in stroke patients. Frontiers in Psychology, 11:548802. https://doi.org/10.3389/fpsyg.2020.548802

6. 6. Soundy, A., Smith, B., Dawes, H., Pall, H., Gimbrere, K., Ramsay, J. (2013). Patient's expression of hope and illness narratives in three neurological conditions a meta-ethnography. Health Psychology Review, 7:177-201. https://doi.org/10.1080/17437199.2011.568856

7. 7. Booker, C. (2004). The seven basic plots: why we tell stories.

8. 8. Ferguson, A., Worral, L., Davidson, B., Hersh, D., Howe, T., Sherratt, S. (2009). Describing the experience of aphrasia rehabilitation through metaphor. Aphasiology, 24; 685-696. https://doi.org/10.1080/02687030903438508

9. 9. Pluta, A., Ulatowska, N., Gawron, N., Sobanska, M., Lojek, E. (2014). A thematic framwrok of illness narrative produced by stroke patients. Disability and Rehabilitation; 37; 1170-1177. https://doi.org/10.3109/09638288.2014.957789

10. 10. Wood, J.P., Connelly, D.M., Maly, M.R., 2010. 'Getting back to real living': a qualitative study of the process of community reintegration after stroke. Clin. Rehabil. 24, 1045-1056. http://dx.doi.org/10.1177/0269215510375901.

11. 11. Salter, K., Hellings, C., Foley, N., Teasell, R., 2008. The experience of living with stroke: a qualitative meta-synthesis. J. Rehabil. Med. 40, 595-602. http://dx.doi. org/10.2340/16501977-0238.

12. 12. Hinckley, J. J. (2006). Finding messages in bottles: living successfully with stroke and aphasia. Topics in Stroke Rehabilitation, 13; 25-36.

13. 13. Mattingly, C. (1998). Healing dramas and clinical plots: the narrative structure of experience. Cambridge University Press, Cambridge.

14. 14. Woodmand, P., Riazi, A., Pereira, C., Jones, F. (2014). Social participation post stroke: a meta-ethnographic review of the experiences and views of community-dwelling stroke survivors. Disability and Rehabilitation, 36: 2031-2043. 
15. 15. Luker, J., Lynch, E., Bernhardsson, S., Bennett, L., Bernhardt, J. (2015). Stroke survivors' experiences of physical rehabilitation: a systematic review of qualitative studies. Archives of physical medicine and rehabilitation, 96; 1698-1708.

16. 16. Labonte, R., Robertson, A. (1996). Delivering the goods, showing our stuff: the case for a constructivist paradigm for health promotion research and practice. Health Education and Behavior, 23; $431-447$. https://doi.org/10.1177/109019819602300404

17. 17. O'Brien, B. C., Harris, I., Beckman, T., Reed, D. A., Cook, D. A. (2014). Standards for reporting qualitative research: A synthesis of recommendations. Academic Medicine, 89: 1-7. doi: 10.1097/ACM.0000000000000388

18. 18. Smith, B. (2018) Generalizability in qualitative research: misunderstandings, opportunities and recommendations for the sport and exercise sciences, Qualitative Research in Sport, Exercise and Health, 10:1, 137-149, DOI: 10.1080/2159676X.2017.1393221

19. 19. Earthly, S., Cronin, A. (2008). Chapter 21 Narrative analysis. In N .Gilbert (Ed). Researching social life, 3rd Edition, London, Sage.

20. 20. Andrews, A. (2020): Quality indicators in narrative research, Qualitative Research in Psychology, DOI: 10.1080/14780887.2020.1769241

21. 21. Soundy, A., Smith, B., Cressy, F., Webb, L. (2010). The experience of spinal cord injury: using Frank's narrative types to enhance physiotherapy undergraduates undererstanding. Physiotherapy, 96: 52-58.

22. 22. Soundy, A., Hemmings, L., Gardiner, L., Rosewilliam, S., Heneghan, N. R., Cronin, K et al., (2021). E-learning communication skills training for physiotherapy students: A two phased sequential mixed methods study,Patient Education and Counseling, 104; 2045-2053. https://doi.org/10.1016/j.pec.2021.01.022.

23. 23. Alawafi, R., Rosewilliam, S., Soundy, A. (2021). An integrative review considering the impact of storytelling and sharing interventions in Stroke. Behavioural Science, 11; 88. https://doi.org/10.3390/bs11060088

24. 24. Kurniawati, N. D., Rihi, P. D., Wahyuni, E. D. (2020). Relationship of family and self-efficacy support to the rehabilitation motivation of stroke patients. EurAsian Journal of BioSciences, 14: 2427-2430.

25. 25. Tropea, S. (2011). 'therapeutic emploment': a new paradigm to explore the interaction between nurses and patients with a long-term illness. Journal of Advanced Nursing, 68;, 939-947. doi: 10.1111/j.1365-2648.2011.05847.x

26. Oyake, K., Suzuki, M., Otaka, Y., Tanaka, S. (2020). Motivational strategies for stroke rehabilitation: A descriptive crosssectional study. Frontiers in Neurology, 11, 553. Doi: 10.3389/fneur.2020.00553 